\title{
Food consumption of larval, young and adult herring and sprat in the Baltic Sea
}

\author{
Fredrik Arrhenius, Sture Hansson
}

Department of Systems Ecology, Stockholm University, S-106 91 Stockholm, Sweden

\begin{abstract}
The total food consumption of herring Clupea harengus L. and sprat Sprattus sprattus (L.), the dominant zooplanktivorous fish in the Baltic Sea, was estimated from published data on abundances, growth, mortality rates and diets using a bioenergetics model. The annual food consumption was $5.0 \times 10^{7}$ tonnes for herring and $2.4 \times 10^{7}$ tonnes for sprat. For herring ca $90 \%$ of the food consumed was zooplankton and the rest mysids and benthos. Larvae and young-of-the-year (YOY) of sprat and herring accounted for 50 and $45 \%$ of the total consumption respectively. Peak consumption rates occurred in August-September. Our estimate for annual consumption of zooplankton by clupeids in the Baltic sea is 4 times higher than previous estimates. One major explanation for this is that we included the consumption by YOY and 1 yr old fish. Our simulations also show that a diet shift, from a mix of zooplankton, mysids and amphipods to only zooplankton, could have a significant effect on fish growth rate. At a fixed biomass consumption, the lower energy density of zooplankton would mean that this shift would decrease growth by about $25 \%$ for older age groups. This decrease is similar to that observed in the Baltic Sea in the late 1980 s.
\end{abstract}

\section{INTRODUCTION}

Two of the most important commercial fishes in the Baltic Sea are herring Clupea harengus L. and sprat Sprattus sprattus (L.). They are mainly zooplanktivores and may consume a considerable proportion of the zooplankton production. Calculations of their food consumption in the Baltic have been made by Thurow (1980, 1984), Elmgren (1984) and Lankov (1988), who estimated the total biomass, production and yield from catch statistics. More precise calculations for older age-classes were made by Aneer (1980) using total production from VPA (Virtual Population Analysis) and mean monthly weight at age. With the exception of Elmgren (1984), these production and consumption estimates have not taken the first year into account. Consumption by all dominating zooplanktivores, including young-of-the-year (YOY) clupeids, has only been estimated in restricted coastal areas (Arndt 1989, Hansson et al. 1990, Rudstam et al. 1992). YOY fish must, however, be of great importance to the total consumption by a fish population. Hewett \& Stewart (1989) estimated that almost $50 \%$ of the total population consumption by the clupeid alewife Alosa pseudoharengus in Lake Michigan (USA) was ac- counted for by larvae and YOY. Rudstam et al. (1992) reached a similar conclusion for a coastal area in the Baltic Sea.

Direct measurements of food consumption by fish are difficult. Field estimates of food consumption, derived from stomach contents and evacuation rates, are often highly variable and require considerable effort (Elliott \& Persson 1978). Therefore, energy budgets and energetics models, in combination with field data on fish growth and water temperature, are important tools for predicting food consumption (Kitchell et al. 1977, Rice \& Cochran 1984). Combined with data on population size, age composition and diets, bioenergetics models can give estimates of the total food consumption of fish populations.

In this study, we apply this approach by using a bioenergetics model for herring developed by Rudstam (1988), together with growth rates, diets and fish abundances for herring and sprat in different parts of the Baltic Sea.

\section{METHODS AND MATERIALS}

The model. A bioenergetics model of individual Baltic herring was developed by Rudstam (1988), using soft- 
ware developed by Hewett \& Johnson (1992). We used this model to simulate seasonal consumption for metamorphosed fish of herring and sprat populations during their first 9 and 7 yr of life respectively. Consumption by larval stages was estimated assuming a gross conversion efficiency of $30 \%$ (Checkley 1984, Kiørboe \& Munk 1986, Houde 1989). In the bioenergetics model, sprat were assumed to have the same characteristics as equally sized herring (Rudstam et al. 1992).

Diet. Information on seasonal- and length-dependent changes in the diet of clupeids from the Baltic Sea is reported by many authors (Popiel 1951, van Khanh et al. 1972, Aneer 1975a, Zalachowski et al. 1975, 1976, Hudd 1982, Raid 1985, Aro et al. 1986, Lankov 1986. Franek 1988, Hansson et al. 1990, Davidyuk et al. 1992, Flinkman et al. 1992, Ostrowski \& Mackiewicz 1992, Rudstam et al. 1992, Starodub et al. 1992). From these data, we derived diet compositions for 4 different size groups of herring, and for each size group, diets were specified for 4 seasons, winter, spring, summer and autumn (Table 1). Sprat were assumed to feed exclusively on zooplankton.

The zooplankton prey were assumed to have a constant energy density of $2850 \mathrm{~J} \mathrm{~g}^{-1}$ wet wt (Laurence 1976). The energy content of mysids increased linearly from $2976 \mathrm{~J} \mathrm{~g}^{-1}$ wet wt in juveniles in July, reaching $3720 \mathrm{~J} \mathrm{~g}^{-1}$ wet wt for adults in October to March (Hakala 1979, Wiktor \& Szaniawska 1988). For amphipods we used $3980 \mathrm{~J} \mathrm{~g}^{-1}$ wet wt for the period when they were consumed, October to March (value for Pontoporeia femorata and Monoporeia affinis ac- cording to Hill et al. 1992). The energy content for the group 'Others', mainly polychaetes and fish, was set to $3500 \mathrm{~J} \mathrm{~g}^{-1}$ (Ankar \& Elmgren 1976, von Bast \& von Ortzen 1976, Cederwall 1977). Constant individual wet wt was assumed for all prey.

Temperature. Water temperature is a major factor in determining bioenergetics of fish. Temperatures experienced by herring differ between age groups during the summer, when young herring are found mainly in warmer water above the thermocline and older fish are found in cooler water and do not show pronounced diel vertical migrations (Rudstam 1988, Hansson et al. 1990). The temperatures occupied by young fish $(0+$ and $1+)$ and by older fish are the average for the top $10 \mathrm{~m}$ and top $20 \mathrm{~m}$ respec-

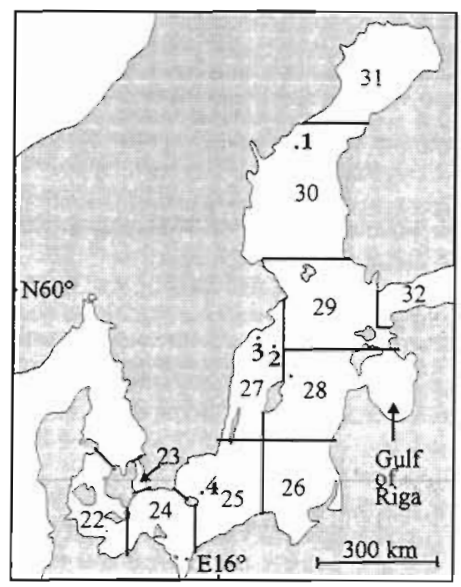

Fig. 1. The Baltic Sea showing the subdivisions (referred to by numbers 22 to 32) used by the International Council for Exploration of the Sea (ICES). Stns 1 to 4 were used to estimate annual temperature cycles (see Fig. 2)

Table 1. Clupea harengus. Seasonal proportions (wet wt) of different prey items in the diets of herring in the Baltic Sea, based on literature data. Winter: January-March; spring: April-June; summer: July-September; autumn: October-December

\begin{tabular}{|c|c|c|c|c|c|}
\hline \multirow[t]{2}{*}{ Size-class } & \multirow[t]{2}{*}{ Season } & \multicolumn{4}{|c|}{ Proportion of diet } \\
\hline & & Zooplankton & Mysids & Amphipods & Others \\
\hline \multirow[t]{4}{*}{$0-100 \mathrm{~mm}(0-5.9 \mathrm{~g})$} & Winter & 1.00 & 0.00 & 0.00 & 0.00 \\
\hline & Spring & 1.00 & 0.00 & 0.00 & 0.00 \\
\hline & Summer & 1.00 & 0.00 & 0.00 & 0.00 \\
\hline & Autumn & 1.00 & 0.00 & 0.00 & 0.00 \\
\hline \multirow[t]{4}{*}{$100-150 \mathrm{~mm}(5.9-21.3 \mathrm{~g})$} & Winter & 0.90 & 0.10 & 0.00 & 0.00 \\
\hline & Spring & 1.00 & 0.00 & 0.00 & 0.00 \\
\hline & Summer & 0.90 & 0.10 & 0.00 & 0.00 \\
\hline & Autumn & 0.80 & 0.10 & 0.05 & 0.05 \\
\hline \multirow[t]{4}{*}{$150-200 \mathrm{~mm}(21.3-51.8 \mathrm{~g})$} & Winter & 0.70 & 0.15 & 0.10 & 0.05 \\
\hline & Spring & 0.95 & 0.00 & 0.00 & 0.05 \\
\hline & Summer & 0.80 & 0.15 & 0.00 & 0.05 \\
\hline & Autumn & 0.70 & 0.15 & 0.10 & 0.05 \\
\hline \multirow[t]{4}{*}{$\geq 250 \mathrm{~mm}(\geq 51.8 \mathrm{~g})$} & Winter & 0.50 & 0.30 & 0.15 & 0.05 \\
\hline & Spring & 0.95 & 0.00 & 0.00 & 0.05 \\
\hline & Summer & 0.65 & 0.30 & 0.00 & 0.05 \\
\hline & Autumn & 0.50 & 0.30 & 0.15 & 0.05 \\
\hline
\end{tabular}




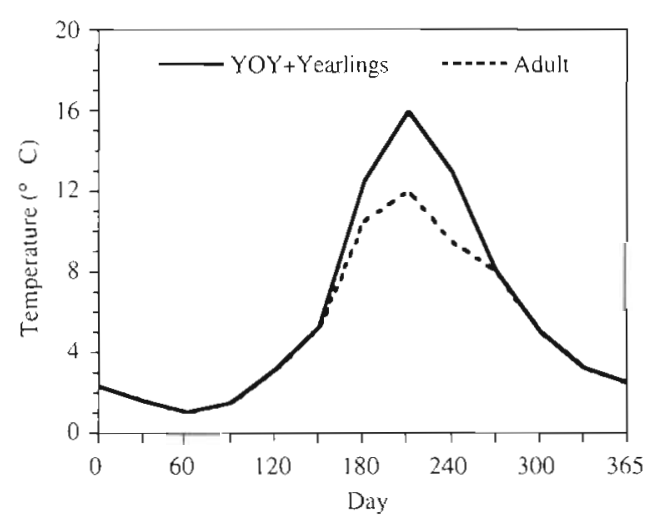

Fig. 2. Clupea harengus, Sprattus sprattus. Average annual cycles of water temperature assumed to be occupied by various age-groups of herring and sprat in the Baltic Sea, based on 3 open sea and 1 coastal stations (1 to 4 in Fig. 1). YOY: young-of-the-year; yearlings: fish of age-class 1 . Sprat follow the yearly cycle of older herring

tively at 4 different stations (Fig. 1) in the Baltic during 1980 to 1990 (Fig. 2). We assumed that all sprat experience the same temperature regime as older herring.

Growth rates. Differentiation of Baltic herring into subpopulations, especially delimitation of areas occupied by different subpopulations, has always been problematic (Ojaveer 1989). For this study we divided the herring stocks into 8 units according to major differences in growth rates of the various populations (Fig. 3). The subdivisions correspond to the International Council for Exploration of the Sea (ICES) statistical rectangles (Fig. 1).

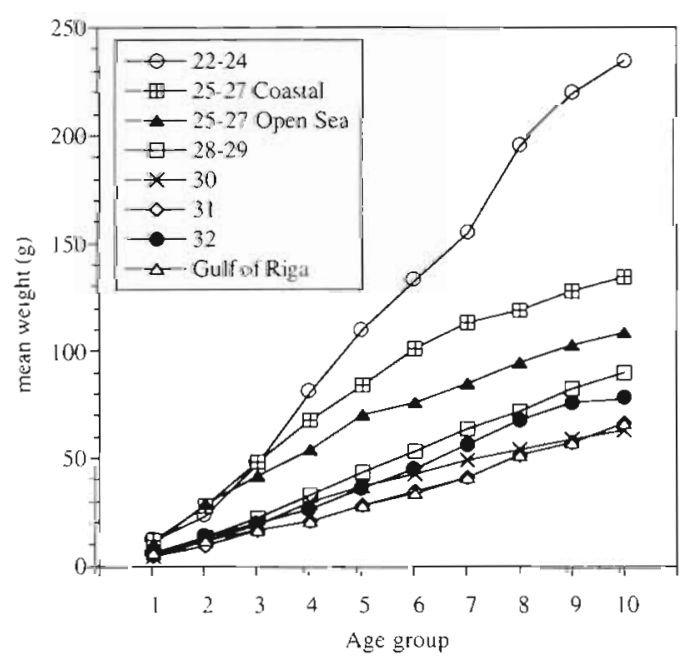

Fig. 3. Clupea harengus. Average weight at capture (1983 to 1990) for 8 different subpopulations of herring in the Baltic Sea (ICES numbering used; Anon. 1987, 1991, Hagström et al $1989,1991\}$
In the ICES reports, the Baltic sprat stock is divided into 3 management units: ICES subdivisions 22 to 25; 26 and 28; and 27 and 29 to 32 (Anon. 1991). In our analysis, we merge these substocks of sprat into 1 population (see Table 3), since differences in growth rate within the Baltic are small (Aps 1989, Ustinova 1990). Data on mortality and diets are also similar for sprat from different parts of the Baltic, justifying this approach.

Abundance and mortality. We did not include interannual variation in fish abundance in the simulations, but instead we used average values from 1983 to 1990 (Tables $2 \& 3$ ) compiled from several reports (Anon. 1987, 1991, Hagström et al. 1991). Abundance estimates for age-classes $\geq 2$ (Tables $2 \& 3$ ) were used to calculate instantaneous daily mortality rates for each age-class. Abundance estimates for the first 2 yr are very uncertain, due to scarcity of relevant information for these life stages. We thus had to make several assumptions, and in order to evaluate effects of these uncertainties we ran alternative simulations, varying some of the parameters (Table 4).

To calculate egg biomass and larval abundance, we assume that the actual spawning stock biomass (SSB) (Anon. 1987, 1991) is $80 \%$ of the estimated SSB on 1 January for herring (Parmanne \& Sjöblom 1981, 1982) and ca $70 \%$ for sprat (Alheit 1988). Furthermore, it was assumed that $50 \%$ of the populations were females and that $20 \%$ of their body weight was gonads with $90 \%$ eggs (Parmanne \& Kuttinen 1991). Each egg weighs about $0.53 \mathrm{mg}$ wet wt for herring and ca $0.26 \mathrm{mg}$ wet wt for sprat (Hempel \& Blaxter 1967, Blaxter \& Hunter 1982, Almatar \& Bailey 1989, Parmanne \& Kuittinen 1991). All populations were assumed to mature at age-class 3 for herring and ageclass 2 for sprat and spawning date was set to 6 June, except for the 2 southernmost populations of herring and that in coastal areas of subdivisions 25 to 27 . For these regions 15 April was used (Ojaveer et al. 1981, Parmanne \& Sjöblom 1982, Rajasilta et al. 1986, Alheit 1988, Rajasilta 1992). For both herring and sprat, $90 \%$ of the eggs were assumed to hatch (Raid 1985, Rajasilta et al. 1986, Aneer 1987, Oulasvirta 1987).

During the first $5 \mathrm{~d}$ the larvae live on the yolk sac. After this period (start of exogenous feeding in Tables 2 to 4) their length is ca $9.0 \mathrm{~mm}(0.7 \mathrm{mg}$ wet wt) for herring and $6.0 \mathrm{~mm}$ (0.5 $\mathrm{mg}$ wet wt) for sprat (Ojaveer 1981, Hudd 1982, Hapette et al, 1991). At this age, the larvae start to feed, and they have lost $20 \%$ in weight (von Westerhagen \& Rosenthal 1979, Øiestad \& Moksness 1981, Gamble et al. 1985). The larvae then increase exponentially in weight and approximately linearly in length (Gamble et al. 1985). We used a daily growth rate of $0.32 \mathrm{~mm}$ during the larval stage. Literature values for clupeids lie between 0.14 and $0.64 \mathrm{~mm} \mathrm{~d}^{-1}$ (Aneer 1979, 
Table 2. Clupea harengus. Herring population numbers, mean weight and biomass (in tonnes) for various age-classes of herring in the Baltic Sea. The values are divided into the 8 different populations according to the ICES rectangle of fishing areas (22 to 32, see Figs. 1 \& 3). Values are based on average annual estimates for each age-class from reports of working groups on assessment of pelagic stocks in the Baltic (Anon. 1987, 1991, Hagström et al. 1989, 1991). The numbers in these reports are presented as age-classes 1 to 9 which are equivalent to our age-classes 2 to 10 . The estimated spawning stock biomass are based on average values from ICES for the different areas and periods. exo.: exogenous

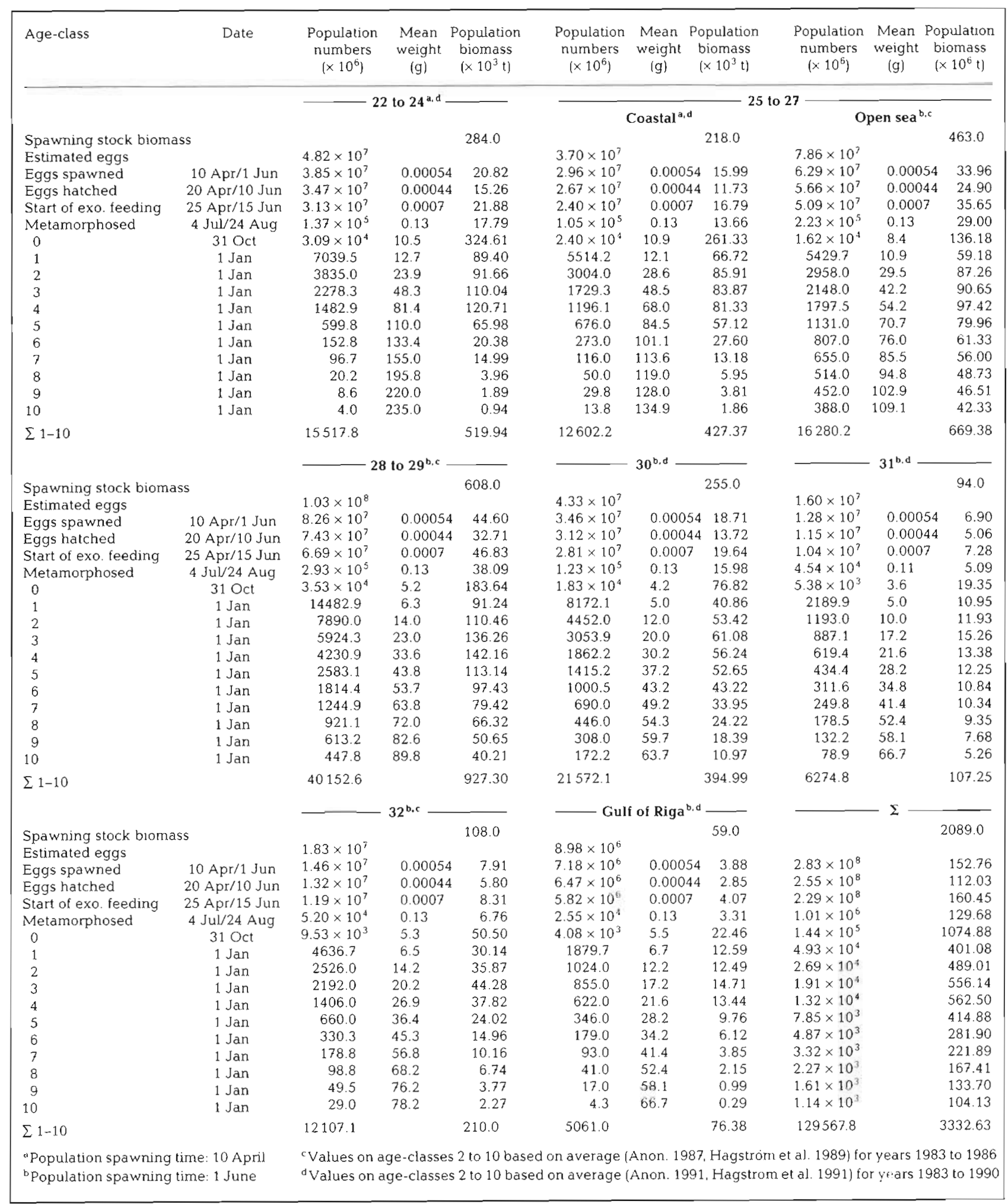


Table 3. Sprattus sprattus. Sprat population biomass, mean weights, numbers and mortalities, for various age-classes in the Baltic Sea. The values are based on 1 Baltic population and average annual (1983 to 1990) estimates for each age-class, from a report of a working group on the assessment of pelagic stocks in the Baltic (Anon. 1991). The numbers in this report are presented as age-class 1 to 9 which are equivalent to our age-classes 2 to 10 . The numbers of younger age-groups (s age-class 1 ) were estimated based on the calculations presented in Table 2. The duration of young-of-the-year period is $128 \mathrm{~d}$

\begin{tabular}{|c|c|c|c|c|c|}
\hline Age-class & Date & $\begin{array}{c}\text { Population } \\
\text { numbers } \\
\left(\times 10^{6}\right)\end{array}$ & $\begin{array}{c}\text { Mean } \\
\text { weight } \\
\text { (g) }\end{array}$ & $\begin{array}{c}\text { Population } \\
\text { biomass } \\
\left(\times 10^{6} \mathrm{t}\right)\end{array}$ & $\begin{array}{c}\text { Daily } \\
\text { mortality }\end{array}$ \\
\hline Estimated eggs & & $2.74 \times 10^{8}$ & & & \\
\hline Eggs spawned & 1 Jun & $1.92 \times 10^{8}$ & 0.000265 & 0.0 & 0.01054 \\
\hline Eggs hatched & $10 \mathrm{Jun}$ & $1.73 \times 10^{8}$ & 0.00044 & 0.0 & 0.02108 \\
\hline Start of exogenous feeding & 15 Jun & $1.56 \times 10^{8}$ & 0.0007 & 109.0 & 0.07758 \\
\hline Metamorphosed & 24 Aug & $6.82 \times 10^{5}$ & 0.13 & 88.7 & 0.01651 \\
\hline 1 & $1 \mathrm{Jan}$ & 82441.1 & 4.3 & 354.5 & 0.00167 \\
\hline 2 & $1 \mathrm{Jan}$ & 44866.7 & 8.5 & 382.3 & 0.00260 \\
\hline 3 & $1 \mathrm{Jan}$ & 17392.9 & 11.9 & 207.3 & 0.00289 \\
\hline 4 & 1 Jan & 6052.0 & 13.9 & 84.2 & 0.00170 \\
\hline 5 & $1 \mathrm{Jan}$ & 3249.5 & 14.7 & 47.9 & 0.00203 \\
\hline 6 & $1 \mathrm{Jan}$ & 1547.5 & 15.9 & 24.7 & 0.00165 \\
\hline 7 & $1 \mathrm{Jan}$ & 846.2 & 16.7 & 14.1 & 0.00245 \\
\hline 8 & 1 Jan & 345.7 & 17.3 & 0.0 & 0.00154 \\
\hline$\sum 1-8$ & & 156741.8 & & 1120.9 & \\
\hline
\end{tabular}

Henderson et al. 1984, Munk et al. 1986, Wespestad \& Moksness 1989, Peltonen 1990, Urho \& Hildén 1990). The clupeid larvae metamorphose at ca $40 \mathrm{~mm}$ (Urho 1992), and $0.13 \mathrm{~g}$ wet wt (Blaxter \& Hunter 1982, Houde 1989). For all populations, the mortality of larvae for the standard run was set to $90 \% \mathrm{mo}^{-1}$ (Raid 1985, Munk et al. 1986) with a larval period of $70 \mathrm{~d}$ from first feeding to metamorphosis (Ojaveer 1981, Houde 1989). However, daily mortality and the duration of the larval period are very unpredictable for most fish species, including clupeids. Therefore, we ran 2 alternative simulations using values above and below those of the standard run to test the importance of these assumptions on the estimated food consumption during these periods. In the alternative simulations we (1) altered the larval mortality to 85 or $95 \% \mathrm{mo}^{-1}$ or (2) assumed larval periods of 50 or $90 \mathrm{~d}$ (Fig. 4).

It is reasonable to assume that the mortality decreases after the larval period (Tables $2 \& 4$ ), but there is very little information for Baltic herring between the age of metamorphosis and recruitment into the fishery. In our simulations, we have not made any a priori assumptions

Table 4. Clupea harengus. Summary of the mortality rates used for the different stocks of herring. Abundance and biomass values are presented in Tables $3 \& 5$. Values for daily mortality in age-classes 2 to 10 and metamorphosis group vary between populations and age-class and depend on the abundances at the start and end of the period. These abundances have been derived as averages for each stock based on ICES data (Anon. 1987, 1991, Hagström et al. 1989, 1991). Different mortality between metamorphosis and age-class 1 depends on the abundance of the stocks at hatch (estimated from spawning stock biomass and the fecundity) and the abundance at 1 January, age-class 2

\begin{tabular}{|c|c|c|c|c|}
\hline Age-class & Date & $\begin{array}{c}\text { Abundance } \\
\text { ( } \% \text { of estimated eggs) }\end{array}$ & $\begin{array}{l}\text { Daily mortality } \\
\text { (fishing and natural mortality) }\end{array}$ & Remarks \\
\hline Estimated number of eggs & \multicolumn{3}{|c|}{100} & \multirow{2}{*}{$20 \%$ mortality } \\
\hline Eggs spawned & 1 Jun & 80 & 0.01054 & \\
\hline Eggs hatched & 10 Jun & 72 & 0.02107 & $10 \%$ mortality \\
\hline Start of exogenous feeding & 15 Jun & 65 & 0.07675 & \multirow{2}{*}{$\begin{array}{l}90 \% \text { mortality per month } \\
\text { Different mortality per } \\
\text { month and population }\end{array}$} \\
\hline Metamorphosis & 24 Aug & 0.28 & $0.0165-0.0290$ & \\
\hline 1 & $1 \mathrm{Jan}$ & \multirow[t]{2}{*}{0.064} & 0.00167 & \multirow{2}{*}{$\begin{array}{l}5 \% \text { mortality per month } \\
\text { Different mortality per } \\
\text { month and population }\end{array}$} \\
\hline $\begin{array}{l}2-10 \\
\text { Sources: }\end{array}$ & $1 \mathrm{Jan}$ & & $0.00035-0.00429$ & \\
\hline $\begin{array}{l}\text { Baltic: Aneer (1979), Parm } \\
\text { Atlantic: Blaxter (1971), Bl } \\
\text { 1989, 1992) }\end{array}$ & $\begin{array}{l}\text { Ie \& Sjöb } \\
\text { I \& Hunt }\end{array}$ & $\begin{array}{l}\text { lom (1981, 1982), Raid ( } \\
\text { ter (1982), Henderson et }\end{array}$ & $\begin{array}{l}\text { 985), Peltonen (1990), Parmann } \\
\text { 1. (1984), Gamble et al. (1985), M }\end{array}$ & $\begin{array}{l}\text { Kuittinen (1991) } \\
\text { k et al (1986), Houde (1987, }\end{array}$ \\
\hline
\end{tabular}


a) Different length of larval stage

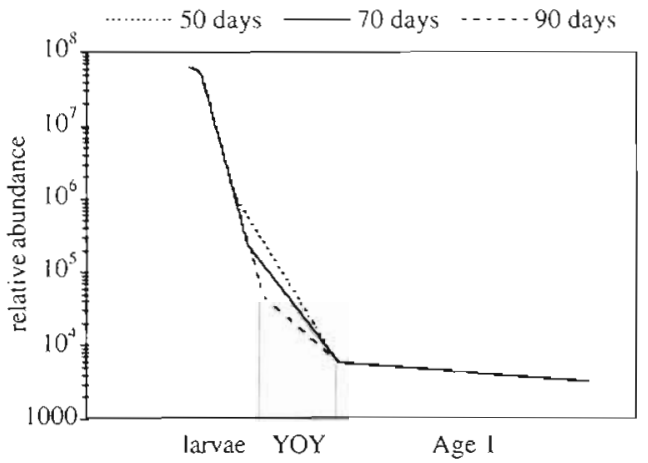

c) Different monthly mortality - Age 1

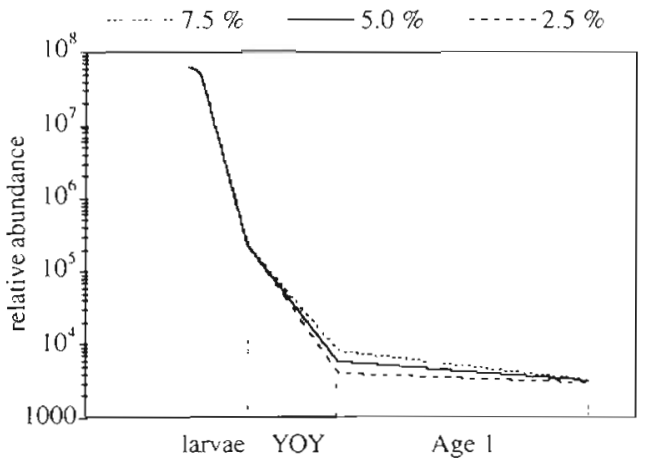

with regards to the mortality of metamorphosed YOY fish. Instead, we adjusted mortality rates for each simulation so YOY abundance by 31 October was ca 3000 fish $\mathrm{ha}^{-1}$ for the standard run and ca 1500 and 4500 fish ha ${ }^{-1}$ for the alternative runs (see below). These values are realistic for at least coastal Baltic areas during that period (Hansson 1993). For fish of age-class 1 we ran simulations with 3 alternative monthly mortality rates, $2.5,5.0$ (standard run) and 7.5\% (Sparholt 1990). This will cause the mortality rate to be higher for YOY fish when the mortality rate for age-class 1 is low and lower when the mortality rate for age-class 1 is high (Fig. 4).

In each simulation, the different subpopulations started with specific numbers of yolk-sac larvae, estimated from the SSB (Tables $2 \& 3$ ). These numbers were then reduced by mortalities described above. The mortality was fixed until exogenous feeding started, then different alternatives were used. Assume, for example, that when exogenous feeding starts, the larval stage lasts for $70 \mathrm{~d}$, during which time the monthly mortality is $90 \%$; in this case, the mortality at age-class 1 is set to $5 \%$ each month. Under these conditions, the mortality during the YOY stage is adjusted in such a way that their number corresponds to an abundance of 3000 fishes ha $\mathrm{h}^{-1}$ by 31 October. In all models, the abundance of fish at onset of age-class 2 b) Different monthly mortality - larval stage

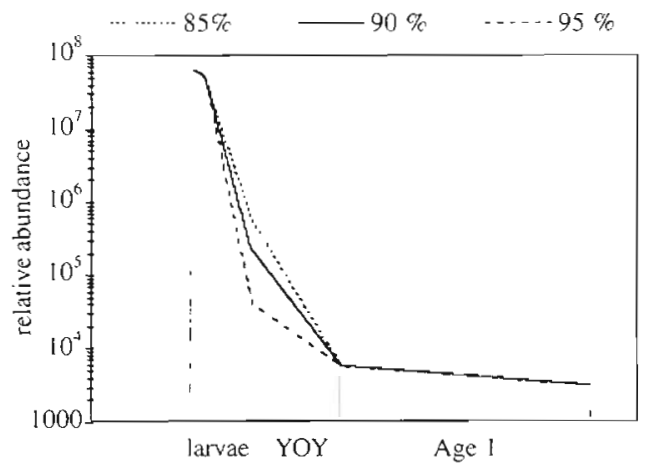

Fig. 4. Clupea harengus. Comparison of abundance of herring in the Baltic Sea under different assumptions of (a) duration of larvae stage (excluding the $10 \mathrm{~d}$ period when the larvae live on the yolk-sac), (b) different monthly mortality during the larval stage and (c) different monthly mortality of age-class 1. The standard run is represented by the medium values. Note the $\log$ scale on the $y$-axis and the time scale on the $x$-axis where the first 2 yr have been divided in 3 sections: larvae, YOY and age-class 1 stages

(on 1 January) was fixed to the value estimated from the ICES data (Tables $2 \& 3$ ).

Energy density. There are few data on energy density of larval herring. First-feeding Pacific herring larvae have an energy density of ca $2800 \mathrm{~J} \mathrm{~g}^{-1}$ wet wt (Eldridge et al. 1977). This should rise to $4550 \mathrm{~J} \mathrm{~g}^{-1}$ wet wt at metamorphosis if water content decreases from $89 \%$ to about $82 \%$ (calculated in Hewett \& Stewart 1989). We assumed a rising energy density with weight

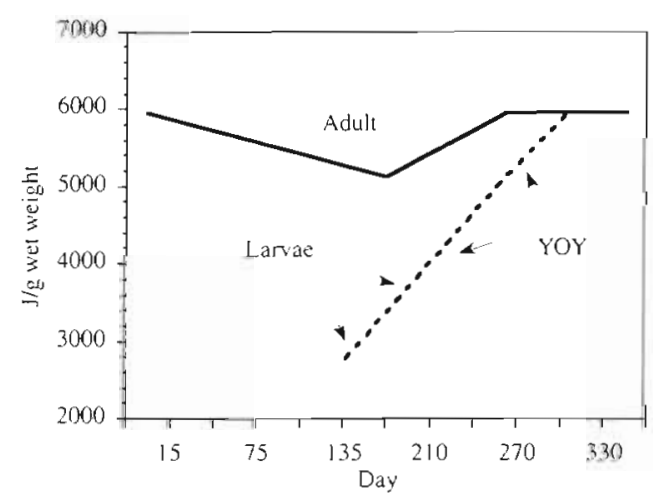

Fig. 5. Clupea harengus. Energy density for herring in $\mathrm{J} \mathrm{g}^{-1}$ wet wt. A progressive rise from larvae and juvenule to adults was assumed 
for larval and YOY herrings (Fig. 5). The energy density of adult herring varies seasonally between 5120 and $5940 \mathrm{~J} \mathrm{~g}^{-1}$ wet wt (Aneer 1975b).

\section{RESULTS AND DISCUSSION}

In our standard run, we estimated the annual food consumption to be $5.0 \times 10^{7} \mathrm{t}$ for herring and $2.4 \times 10^{7}$ t for sprat (Table 5), corresponding to $12.4 \mathrm{~g} \mathrm{C}$ $\mathrm{m}^{-2} \mathrm{yr}^{-1}$ and $6.0 \mathrm{~g} \mathrm{C} \mathrm{m}^{-2} \mathrm{yr}^{-1}$ respectively [carbon content is $10 \%$ of the wet wt, (von Bast \& von Ortzen 1976)] This is at least 4 times as high as other estimates for herring (Aneer 1980, Thurow 1980, 1984, Elmgren 1984), and for sprat (Elmgren 1984, Lankov 1988). A closer look at the data by Elmgren (1984), who included all size groups in his analysis, shows that the biomasses of herring are similar for all populations except that in the Baltic proper. This difference explains to a large extent his lower values for food consumption of herring. The much higher estimates of consumption by sprat is partly explained by higher abundances of young age-classes than assumed by other authors (Elmgren 1984, Lankov 1988). For herring about $90 \%$ of the total food consumption consists of zooplankton, mainly mesozooplankton (Fig. 6). This value is higher than that used by Aneer (1980) and Elmgren (1984). We used data from offshore populations, which should be more representative of the total Baltic herring population, while Aneer (1980) and Elmgren (1984) based their calculations on diets from coastal areas where mysids and benthos may be more abundant. It is also possible that there has been a shift in the diet of herring during the 1980s, and that this has influenced our data (see discussion on the possibility of such a shift below).

There are few values for the average zooplankton production in the Baltic. Elmgren (1984) used a value of $23 \mathrm{~g} \mathrm{C} \mathrm{m}^{-2} \mathrm{yr}^{-1}$ and Lankov (1988) used $30 \mathrm{~g} \mathrm{C} \mathrm{m}^{-2}$ $\mathrm{yr}^{-1}$ in the northeastern Baltic, but these are high compared to other investigations (i.e. Aneer 1979, Hernroth \& Ackefors 1979). Using the above values from Elmgren (1984) and Lankov (1988), sprat and herring consume $80 \%$ or $60 \%$ of the zooplankton production. This is high considering that there are also other species, e.g. mysids and larval stages of most fish species, that feed on zooplankton (Hansson et al. 1990, Rudstam et al. 1992). Zooplankton production differs in different areas, decreasing from south to north. In the Bothnian Bay, the northernmost basin of the Baltic Sea, the production was estimated as only about 2.5 to $3.7 \mathrm{~g}$ $\mathrm{C} \mathrm{m}^{-2} \mathrm{Yr}^{-1}$ in the open sea (Kankaala 1987), and for this area our simulations gave a zooplankton consumption by herring and sprat of $3.5 \mathrm{~g} \mathrm{C} \mathrm{m}^{-2} \mathrm{yr}^{-1}$.

Prey other than zooplankton constitute only about $10 \%$ of the estimated food consumption of herring. The amphipods made up $1.5 \times 10^{6} \mathrm{t}$, and mysids $4 \times$ $10^{6}$ t annually (see Fig. 8), corresponding to $0.4 \mathrm{~g} \mathrm{C} \mathrm{m}^{-2}$ $\mathrm{yr}^{-1}$ and $1.0 \mathrm{~g} \mathrm{C} \mathrm{m}^{-2} \mathrm{yr}^{-1}$ respectively.

About $15 \%$ of the total annual zooplankton consumption by the Baltic Sea herring and sprat may be

Table 5. Clupea harengus, Sprattus sprattus. Comparisons of gross population, consumption, production, gamete production (all in tonnes), and average biomass conversion efficiency (production plus gamete production/consumption) for various age-classes of herring and sprat

\begin{tabular}{|c|c|c|c|c|c|c|c|c|c|c|}
\hline \multirow[t]{3}{*}{ Age-class } & \multicolumn{5}{|c|}{ Clupea harengus } & \multicolumn{5}{|c|}{ Sprattus sprattus } \\
\hline & \multirow{2}{*}{$\begin{array}{c}\text { Pop. } \\
\text { cons. } \\
\left(\times 10^{3} \mathrm{t}\right)\end{array}$} & \multirow{2}{*}{$\begin{array}{l}\text { Pop. } \\
\text { prod. } \\
\left(\times 10^{3} t\right)\end{array}$} & \multirow{2}{*}{$\begin{array}{l}\text { Gamete } \\
\text { mass } \\
\left(\times 10^{3} t\right)\end{array}$} & \multicolumn{2}{|c|}{ Conv effic. $(\%)$} & \multirow{2}{*}{$\begin{array}{c}\text { Pop. } \\
\text { cons. } \\
\left(\times 10^{3} \mathrm{t}\right)\end{array}$} & \multirow{2}{*}{$\begin{array}{l}\text { Pop. } \\
\text { prod. } \\
\left(\times 10^{3} t\right)\end{array}$} & \multirow{2}{*}{$\begin{array}{c}\text { Gamete } \\
\text { mass } \\
\left(\times 10^{3} \mathrm{t}\right)\end{array}$} & \multicolumn{2}{|c|}{ Conv effic. $(\%)$} \\
\hline & & & & Pop. ${ }^{\circ}$ & Ind. ${ }^{\circ}$ & & & & Pop." & Ind. ${ }^{b}$ \\
\hline Larva & 7378.2 & 2508.6 & 0 & 34.0 & 30.0 & 3930.0 & 1333.0 & 0 & 33.9 & 30.0 \\
\hline Metamorphosed & 15164.8 & 2827.0 & 0 & 18.6 & 13.6 & 8446.0 & 1517.0 & 0 & 18.0 & 11.3 \\
\hline 1 & 7418.3 & 360.7 & 0 & 4.9 & 5.2 & 5749.0 & 224.9 & 0 & 2.7 & 3.9 \\
\hline 2 & 5201.9 & 270.6 & 0 & 5.2 & 4.0 & 3399.0 & 45.6 & 0 & 0.8 & 2.4 \\
\hline 3 & 4438.3 & 190.0 & 22.2 & 4.3 & 3.0 & 1361.0 & 9.4 & 11.0 & 0.3 & 1.2 \\
\hline 4 & 3368.1 & 92.1 & 26.4 & 2.7 & 2.6 & 696.6 & 1.8 & 5.4 & 0.1 & 0.5 \\
\hline 5 & 2442.6 & 62.2 & 18.2 & 2.5 & 1.8 & 372.6 & 0.9 & 3.0 & 0.1 & 0.6 \\
\hline 6 & 1692.0 & 38.9 & 13.2 & 2.3 & 1.7 & 200.9 & 0.4 & 1.6 & 0.1 & 0.4 \\
\hline 7 & 1272.9 & 24.7 & 9.1 & 1.9 & 1.7 & 96.0 & 0.4 & 0.8 & 0.2 & 0.3 \\
\hline 8 & 886.6 & 19.0 & 7.0 & 2.1 & 1.1 & 49.2 & 0.1 & 0.4 & 0.1 & 0.3 \\
\hline 9 & 686.3 & 11.4 & 5.4 & 1.7 & 0.9 & & & & & \\
\hline 10 & 549.3 & 9.8 & 4.6 & 1.8 & 0.7 & & & & & \\
\hline$\sum$ all & 50499.4 & 6415.0 & & & & 24300.3 & 3133.5 & & & \\
\hline$\sum 1-10(1-8)$ & 27956.3 & 1079.4 & 106.1 & & & 11924.3 & 283.5 & 22.2 & & \\
\hline \multicolumn{11}{|c|}{$\begin{array}{l}\text { The population conversion efficiency is expressed as the ratio between population production and population consumption } \\
\text { b The individual conversion efficiency is expressed as the ratio between growth and food consumption of an individual fish, from } \\
1 \text { January to } 31 \text { December. This efficiency is different from that of the population, since the latter is influenced by continuous } \\
\text { mortality during this period }\end{array}$} \\
\hline
\end{tabular}



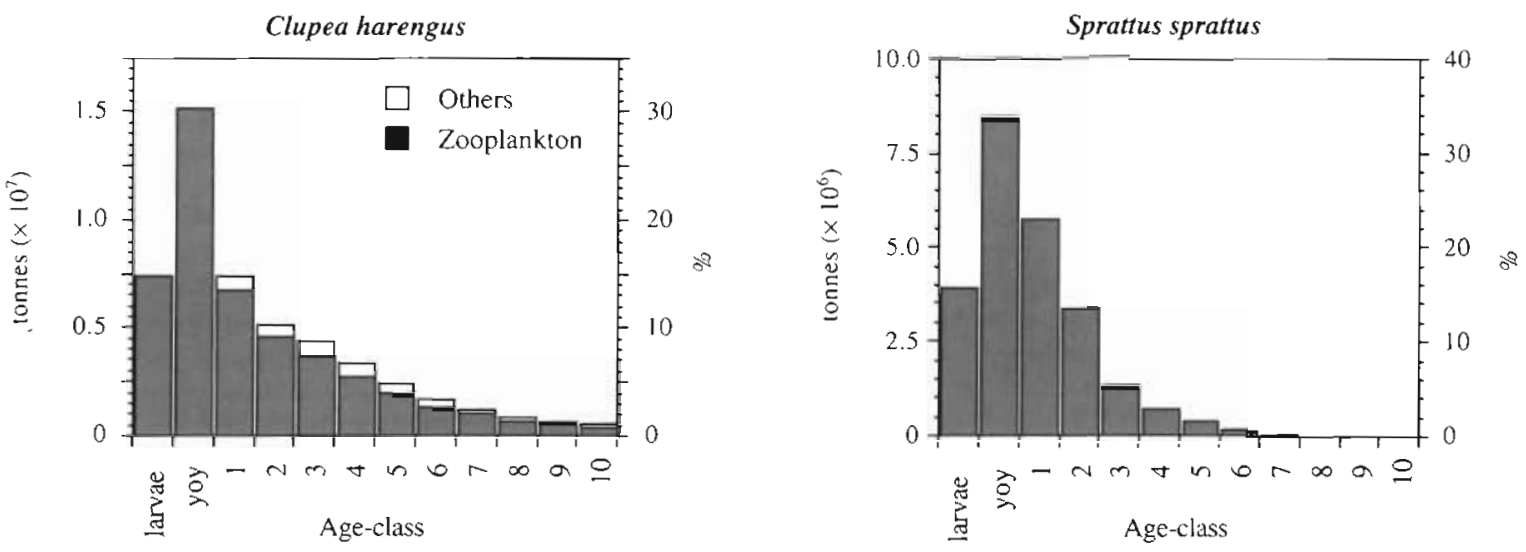

Fig. 6. Clupea harengus, Sprattus sprattus. Total predation by herring and sprat in the Baltic Sea for all prey types by age-class Duration of age-classes: larvae, $70 \mathrm{~d}_{i}$ metamorphosed YOY, 128 or $173 \mathrm{~d}$ for different stocks

attributed to the larval fish and together with the metamorphosed YOY they account for almost 50 and $45 \%$ of the total consumption of zooplankton by sprat and herring respectively (Fig. 6). This is similar to values given by Rudstam et al. (1992) for a coastal area in the Baltic Sea and also for alewife in Lake Michigan (Hewett \& Stewart 1989). During the first year, sprat and herring may also consume plankton species with lower energy densities than assumed in our calculation. Phytoplankton, rotifers and cladocerans have been shown to be very important especially for sprat larvae smaller than $30 \mathrm{~mm}$ (Lankov 1988). If the larvae feed on plankton with lower energy density than we have assumed, this will further increase their predation pressure on the zooplankton community. The food consumption of age-class 1 fish accounted for $15 \%$ of herring and $25 \%$ of the sprat population's total consumption. Age-class 2 and older fish contributed $40 \%$ of the total herring consumption and $25 \%$ of the total sprat consumption. The differences between herring and sprat in the relative consumption by different ageclasses is explained by the shorter life span of sprat (Fig. 6). If consumption values for age-class 2 and older for both species are compared with results presented by Aneer (1980), Thurow (1984) and Lankov (1988), who only considered these older fish, the results are somewhat similar. This clearly shows that the reasons for the large differences between our and their consumption estimates resulted mainly from our inclusion of young fish and that this is very important in this kind of study.

Our analysis predicts that the consumption of zooplankton by the herring and sprat populations varies with season and peaks during July to October (Fig. 7). This peak was later than that found for sprat in the southern Baltic by van Khanh et al. (1972). Their data
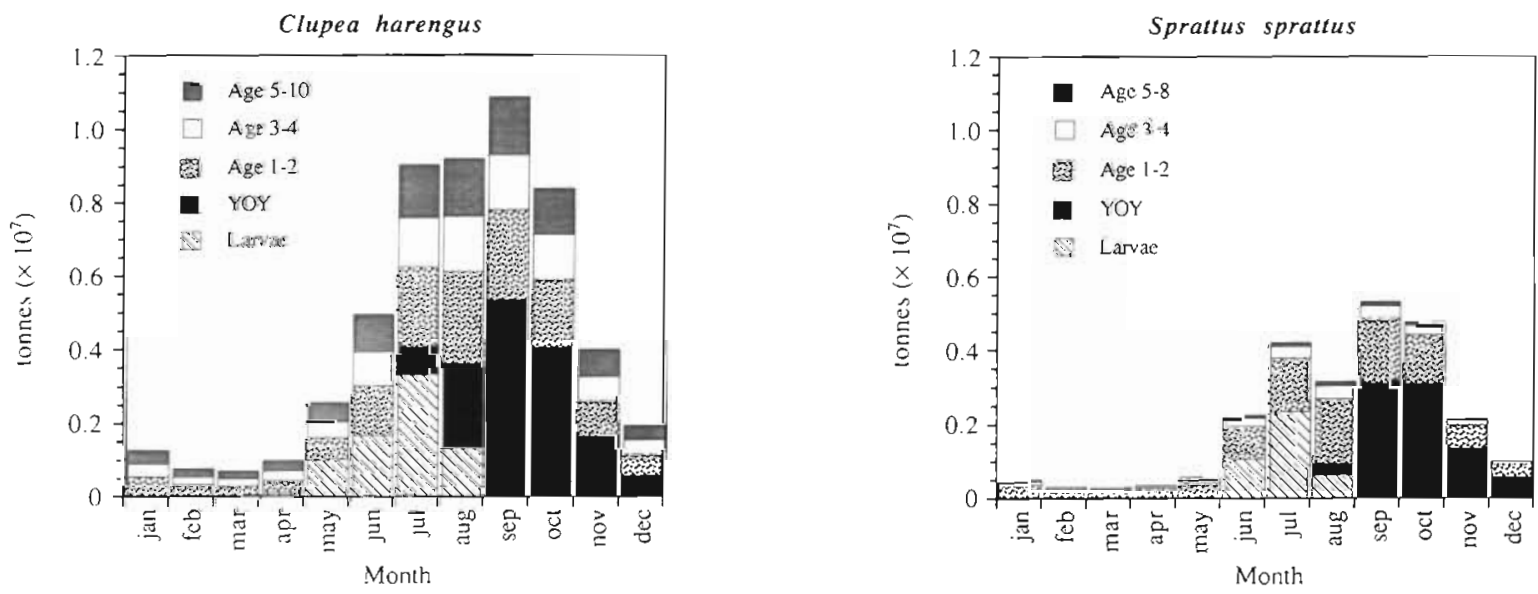

Fig. 7 Clupea harengus. Sprattus sprattus. Total predation by herring and sprat in the Baltic Sea for all prey types by month of year and age-class (see legends). Duration of age-classes: larvae, 70 d; metamorphosed YOY, 128 or $173 \mathrm{~d}$ for different stocks 
suggested that the most intensive feeding took place from April to July and that feeding was moderate from August to October. However, they only studied the gut fullness, without taking evacuation rates into account. Aps (1989) suggested that the highest feeding activity and stomach fullness of sprat occurs during the summer in the northern part of the Baltic. High consumption of zooplankton by herring in late summer and autumn has been used to explain the autumn decline in zooplankton biomass in coastal waters (Hansson et al. 1990, Rudstam et al. 1992). During late autumn and winter the food consumption decreases. This is the result of slow growth, low temperatures and partly a shift in diet to prey with higher energy density.

Our results, and those presented by Hansson et al. (1990) and Rudstam et al. (1992), imply that the fish predation on zooplankton can be intensive and can even influence the annual dynamics of zooplankton. To understand these processes, more information on seasonal food consumption patterns of clupeids, especially the first 2 year-classes, is needed. The most unpredictable data seems to be for YOY. For several other species extrapolation of allometric functions of respiration and consumption from adult fish to larvae and juveniles has been inappropriate (Hewett \& Johnson 1992). The peak in zooplankton consumption (Fig. 8) occurs a little later than the estimated peak in zooplankton production (Johansson et al. 1993). This could be a real difference in timing, but it could also result, for example, from errors in monthly growth rates of the fish or the temperature dependence of the metabolism of the fish. Furthermore, the studies by Johansson et al. (1993) were from a coastal area in the northern Baltic proper, and conditions could be different in offshore areas and in more southern parts of the Baltic. In general we believe, however, that our estimates of the total annual consumption by herring and sprat reflect more accurately the real situation.

Different assumptions on growth and mortality rates had dramatic effects on the estimated food consumption of herring and sprat, especially for yearlings (cf. Laurence 1990). The most dramatic effect occurred by changing the length of the larval-stage period. When we decreased this period from 70 to $50 \mathrm{~d}$, but kept
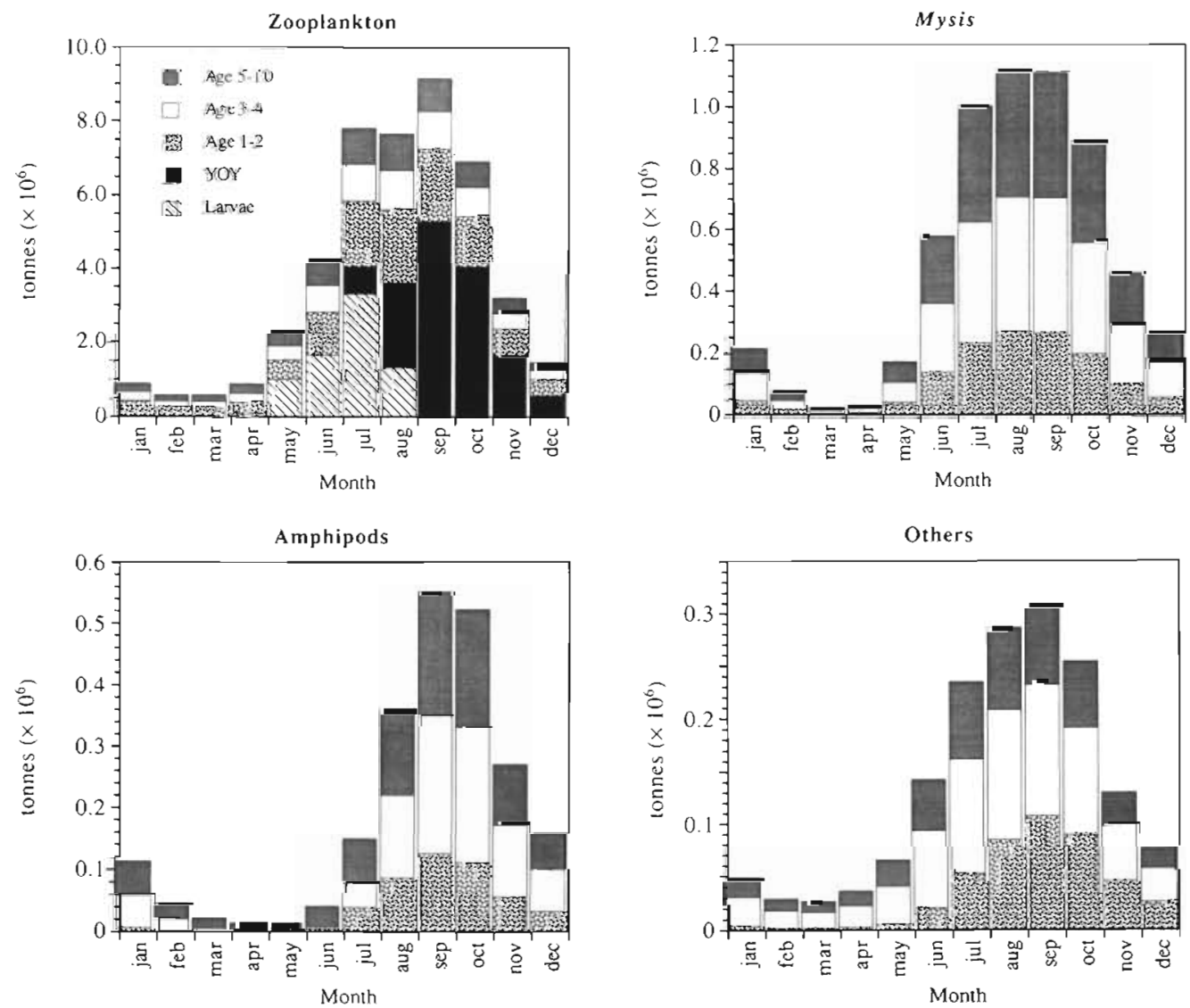

Fig. 8. Clupea harengus. Comparison of monthly predation on 4 different prey types [zooplankton, Mysis sp., amphipods (mainly Monoporeia and/or Pontoporeia sp.l and others] by the Baltic Sea herring population, partitioned by age-class. Note the different scales on the $y$-axis 
the end weight and monthly mortality of $90 \%$, we increased the number of fish entering the YOY period. To compensate for this increase in the YOY, the daily mortality during this period was increased from 0.0236 to 0.0314 . In this way, the number of fish enter-
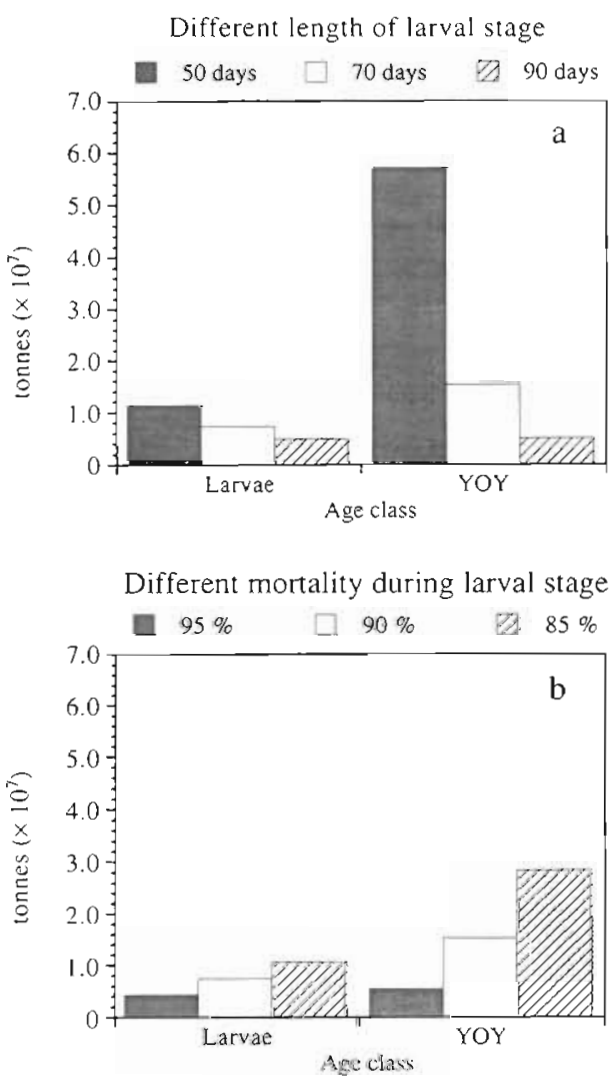

Different mortality of age class 1

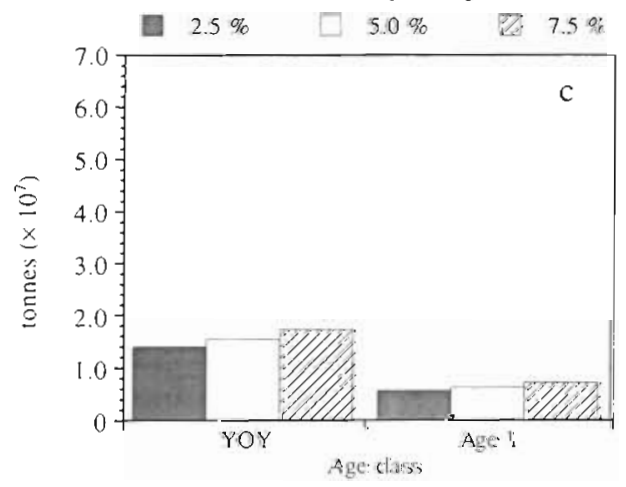

Fig. 9. Clupea harengus. Comparison of food consumption by the average herring population in the Baltic Sea under different assumptions of (a) duration of larvae stage, (b) different monthly mortality during the larval stage, and (c) different monthly mortality of age-class 1 The standard run is represented by the medium values. Difference in the populations' total food consumption compared with the medium values was: (a) $50 \mathrm{~d},+70 \%$, and $90 \mathrm{~d},-14 \%$; (b) $95 \%$ mortality, $-29 \%$, and $85 \%$ mortality, $+37 \%$; and (c) $2.5 \%$ mortality, $-4 \%$, and $7.5 \%$ mortality, $+6 \%$ ing age-class 1 , on 1 January, was the same irrespective of the length of the larval period (Fig. 4a). These changes, and corresponding increases in the larval period, had strong effects on the estimated consumptions (Fig. 9a).

Another test of the sensitivity of the model for different assumptions was made by changing the larval mortality rate, but keeping the length of the larval period to $70 \mathrm{~d}$. Increasing the monthly larval mortality from 90 to $95 \%$ decreased the number of fish entering the YOY group by $80 \%$. To counterbalance this increased mortality, we decreased the mortality of the YOY, so that the number of fish entering age-class 1 was the same in both simulations (Fig. 4b). When changing the length of the larval period (see above), changes in larval mortality had considerable effect on the estimated food consumption (Fig. 9b)

Our third test of the model sensitivity was to change the mortality rate for age-class 1 . Different mortality rates during this period were achieved by starting age-class 1 with different fish numbers, always ending the period with a fixed number of fish, as given by the ICES stock assessments. Different numbers entering age-class 1 were derived by adjusting the mortality during the YOY period (Fig. 4c). The results of these simulations (Fig. 9c) indicate that changes in assumptions with regard to the mortality of the age-class 1 fishes were less critical to the total food consumption than the changes we made for the larval period.

In the last decade the growth rate of herring has declined markedly in the Baltic (Hagström et al. 1991, Aro et al. 1992, Parmanne 1992). This reduction is larger for older herring than for younger $115 \%$ for age-classes 2 to 4 and $25 \%$ for age-class $>4$ ), and Kostrichkina \& Ojaveer (1982) suggested that such decreases in growth could be the result of decreased proportions of large prey organisms in the diet of herring. To test this, we estimated the volume of prey eaten by herring when the diet followed Table 1 . We then replaced all non-zooplankton prey with the same biomass of zooplankton, resulting in a decreased energy intake due to the lower energy density of zooplankton. This resulted in a significantly decreased growth rate (Fig. 10), similar to that described by Hagström et al. (1991). One possible explanation of the decreased growth of herring could thus be that low oxygen concentrations in bottom waters or other factors have reduced the production of large benthic and epibenthic crustaceans such as mysids and amphipods (Kostrichkina et al. 1987). Long-term monitoring data (1983 to 1990) on the abundance of Baltic benthos do not, however, support this explanation (Ankar 1985. Cederwall 1989). The mysids, which are the dominant macrocrus- 


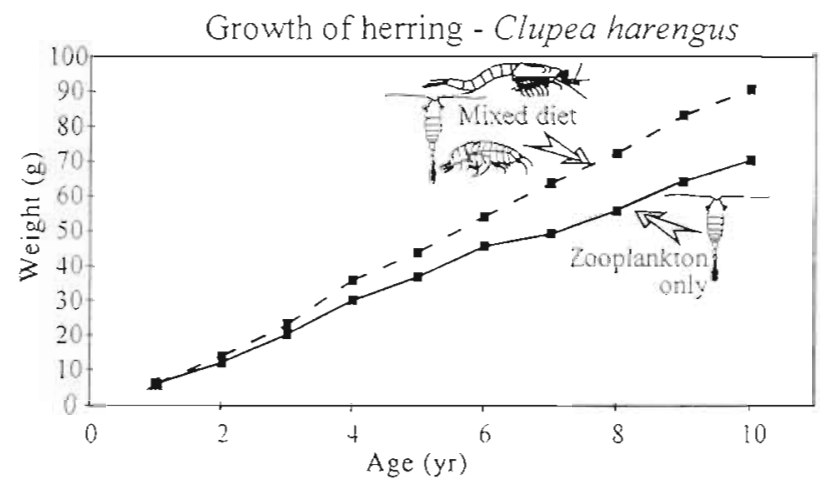

Fig. 10. Clupea harengus. Growth of herring in the northern Baltic proper (ICES area 28-29). Field data (= mixed diet) were compared to estimated growth if the diet consisted only of zooplankton, and the fish consumed the same weight of food as with mixed diet

taceans used by herring, were unfortunately not sampled properly in this study. Therefore due to this lack of data, we cannot exclude the possibility that a diet shift explains this decreased growth of herring.

\section{CONCLUSIONS}

Our calculations show that Baltic herring and sprat exert a strong predation pressure on zooplankton. Furthermore, the results indicate that young-of-theyear and 1 yr old herring and sprat are very important zooplanktivores. Therefore, the magnitude of zooplanktivory by herring and sprat is sensitive to alternative, but equally reasonable, assumptions on growth and survival of these early life stages. Further studies on these life stages are thus needed to understand trophic interactions and the production potential of clupeids in the Baltic Sea.

Acknowledgements. We are grateful to Lars Rudstam and Ragnar Elmgren for the support and valuable criticisms of the manuscript. Miguel Rodrigues helped with compiling data for the model. Financial support was provided by the Swedish Environmental Protection Agency and Swedish Natural Science Research Council.

\section{LITERATURE CITED}

Alheit, J. (1988). Reproductive biology of sprat (Sprattus sprattus): factors determining annual egg production. J. Cons. int. Explor. Mer 44: 162-168

Almatar, S. M., Bailey, R. S. (1989). Variation in the fecundity and egg weight of herring (Clupea harengus L.). Part I. Studies in the Firth of Clyde and northern North Sea. J. Cons. int. Explor. Mer 45: 113-124

Aneer, G. (1975a). A two year study of the Baltic herring in the Askö-Landsort area, 1970-1972. Contrib. Askö Lab., Univ. of Stockholm 8: 1-36
Aneer, G. (1975b). Composition of food of the Baltic herring (Clupea harengus v. membras L.), fourhorn sculpin (Myoxocephalus quadricornis L.) and eel-pout (Zorces viviparus L.) from deep soft bottom trawling in the Askö-Landsort area during two consecutive years. Merentutkimuslaitoksen Julk. Havskorskningsinst. Skr. 239: 146-154

Aneer, G. (1979). On the ecology of the Baltic herring: studies on spawning areas, larval stages, locomotory activity pattern, respiration, together with estimates of production and energy budgets. Ph.D. thesis, Univ, of Stockholm

Aneer, G. (1980). Estimates of feeding pressure on pelagic and benthic organisms by Baltic herring (Clupea harengus v. membras L.). Ophelia, Suppl. 1: 265-275

Aneer, G. (1987). High natural mortality of Baltic herring (Clupea harengus) eggs caused by algal exudates? Mar. Biol. 94: 163-169

Ankar, H. (1985). The environmental monitoring program in Sweden - Annual Report 1985, on benthic macrofauna monitoring in the Baltic proper. Mimeo., Askö Laboratory, Institute of Marine Ecology, Stockholm University, p. 1-78 (in Swedish with English summary)

Ankar, S., Elmgren, R. (1976). The benthic macro- and meiofauna of the Askö-Landsort Area (Northern Baltic Proper) - a stratified random sampling survey. Contrib. Askö Lab., Univ. of Stockholm 11. 1-115

Anon. (1987). Report of the working group on assessment of the pelagic stocks in the Baltic. Part 1 Comm. Meet. int. Coun. Explor Sea C.M.-ICES 1987/Assessment 20: $1-163$

Anon. (1991). Report of the working group on assessment of the pelagic stocks in the Baltic. Comm. Meet. int. Coun. Explor. Sea C.M.-ICES 1991/Assessment 18: 1-142

Aps, R. (1989). Sprat stock dynamics in the northern Baltic, 1950-1987 Rapp. P.-v. Réun. Cons. int. Explor Mer 190: $219-222$

Arndt, H. (1989). Zooplankton production and its consumption by planktivores in a Baltic inlet. In: Klekowski, R. Z., Styczynska-Jurewicz, E., Falkowski L. (eds.) 21st Eur. Mar. Biol. Symp.: Gdansk, Poland, 1986. Inst of Oceanology, Polish Academy of Sciences, p. 205-214

Aro, E., Uitto, A., Vourinen, I., Flinkman, J. (1986). The food selection of Baltic herring in late summer in the northern Baltic Sea. Comm. Meet. int. Coun. Explor. Sea C.M.-ICES 1986/J:26: 1-19

Aro, E., Kotilainen, P., Flinkman, J. (1992). Changes in the growth rate of Baltic herring: why some specimens are starved in the northern Baltic. Comm. Meet. int. Coun. Explor. Sea C.M.-ICES 1992/J:4: 1-22

Blaxter, J. H. S. (1971). Feeding and condition of Clyde herring larvae. Rapp. P.-v. Réun. Cons. int. Explor. Mer 160: $129-136$

Blaxter, J. H. S., Hunter, J R. (1982). The biology of the clupeoid fishes. Adv. mar. Biol. 20: 1-223

Cederwall, H. (1977). Annual macrofauna production of a soft bottom in the northern Baltic proper. In: Keegan, B. F., Ceidigh, P. O., Boaden, P. J. S. (eds.) Biology of benthic organisms. 11th Eur. Mar. Biol. Symp.: Galway, Ireland, 1976. Pergamon Press, Oxford, p. 155-164

Cederwall, H. (1989). The National Swedish Environmental Monitoring Programme (PMK): soft-bottom macrofauna monitoring in the coastal areas of the Baltic proper 1989 - Annual report. Mimeo., Department of Systems Ecology, Stockholm University, p. 1-64 (in Swedish with English summaryl

Checkley, D. M. Jr (1984). Relations of growth to ingestion for larvae of Atlantic herring Clupea harengus and other fish. Mar. Ecol. Prog. Ser. 18: 215-224 
Davidyuk, A., Fetter, M. Hoziosky, S. (1992). Feeding and growth of Baltic herring. Comm. Meet. int. Coun. Explor. Sea C.M.-ICES 1992/J:27: 1-8

Eldridge, M. B., Echeverria, T., Whipple, J. A. (1977). Energetics of Pacific herring (Clupea harengus pallasi) embryos and larvae exposed to low concentrations of benzene, a monoaromatic component of crude oil. Trans. Am. Fish. Soc. 106: 452-461

Elliott, J., Persson, L. (1978). The estimation of daily rates of food consumption for fish. J. Anim. Ecol. 47: 977-991

Elmgren, R. (1984). Trophic dynamics in the enclosed, brackish Baltic Sea. Rapp. P.-v. Réun. Cons. int. Explor. Mer 183: $152-169$

Flinkman, J., Vuorinen, I., Aro, E. (1992). Planktivorous Baltic herring (Clupea harengus) prey selectively on reproducing copepods and cladocerans. Can. J. Fish. Aquat. Sci. $49(1): 73-77$

Franek, D. (1988). 0+ smelt (Osmerus eperlanus L.) and herring (Clupea harengus L.) in the food chain of the Barter Bodden. ICES $1988 \mathrm{BAL} / \mathrm{J}: 13: 1-16$

Gamble, J. C., MacLachlan, P., Seaton, D. D. (1985). Comparative growth and development of autumn and spring spawned Atlantic herring larvae reared in large enclosed ecosystems. Mar. Ecol. Prog. Ser. 26: 19-33

Hagström, O., Palmén, L.-E., Håkansson, N., Kästner, D., Rothbarth, H. B., Grygiel, W., Wyszynski, M. (1989). Acoustic estimates of the herring and sprat stocks in the Baltic proper October 1988. Comm. Meet. int. Coun. Explor. Sea C.M.-ICES 1989/J:26: 1-25

Hagström, O., Palmén, L.-E., Håkansson, N., Kästner, D., Rothbarth, H. B., Grygiel, W., Wyszynski, M. (1991). Acoustic estimates of the herring and sprat stocks in the Baltic proper October 1990. Comm. Meet. int. Coun. Explor. Sea C.M.-ICES 1991/J:34: 1-25

Hakala, I. (1979). Seasonal variation in the carbon and energy contents and assimilation of a Mysis relicta population in Pääjärvi, southern Finland. Annls Zool. fenn. 16: 129-137

Hansson, S. (1993). Variation in hydroacoustic abundance of pelagic fish. Fish. Res.: 16: 203-222

Hansson, S., Larsson, U., Johansson, S. (1990). Selective predation by herring and mysids, and zooplankton community structure in a Baltic Sea coastal area. J. Plankton Res. 12(5): $1099-1116$

Hapette, A. M., Coombs, S., Williams, R., Poulet, S. A. (1991). Variation in Vitamin $C$ content of sprat larvae (Sprattus sprattus) in the Irish Sea. Mar. Biol. 108: 39-48

Hempel, G., Blaxter, J. H. S. (1967). Egg weight in Atlantic herring. J. Cons perm. int. Explor. Mer 31(2): 170-195

Henderson, P. A., Whitehouse, J. W., Cartwright, G. H. (1984). The growth and mortality of larval herring, Clupea harengus L., in the River Blackwater Estuary, 1978-1980. J. Fish. Biol. 24: 613-622

Hernroth, L., Ackefors, H. (1979). The zooplankton of the Baltic proper - a long term investigation of the fauna, its biology and ecology. Rep. Fish. Bd Sweden Inst. mar. Res. 2: 1-59

Hewett, S. W., Johnson, J. L. (1992). Fish bioenergetics model 2. An upgrade of a generalized bioenergetics model of fish growth for microcomputers. University of Wisconsin Sea Grant Technical Report No. WIS-SG-92-250, 2nd edn., Madison, p. 1-79

Hewett, S. W., Stewart, D. J. (1989). Zooplanktivory by alewives in Lake Michigan: ontogenetic, seasonal, and historical pattern. Trans. Am. Fish. Soc. 118: 581-596

Hill, C., Quigley, M. A., Cavaletto, J. F., Gordon, W. (1992) Seasonal changes in lipid content and composition in the benthic amphipods Monoporeia affinis and Pontoporeia femorata. Limnol Oceanogr. $37 \cdot 1280-1289$
Houde, E. D. (1987). Fish early life dynamics and recruitment variability. Am. Fish. Soc. Symp. 2: 17-29

Houde, E. D. (1989). Comparative growth, mortality and energetics of marine fish larvae: temperature and implied latitudinal effects. Fish. Bull. U.S. 87: 471-495

Houde, E. D. (1992). Are marine and freshwater larvae different? Comm. Meet. int. Coun. Explor. Sea C.M.-ICES 1992/L:26: 1-13

Hudd, R. (1982). Feeding of Baltic herring larvae (Clupea harengus L.) in the Gulf of Finland. Finn. Fish. Res. 4: $27-34$

Johansson, S., Hansson, S., Araya-Nunez, O. (1993). Temporal and spatial variation of coastal zooplankton in the Baltic Sea. Ecography (in press)

Kankaala, P. (1987). Structure, dynamics and production of mesozooplankton community in the Bothnian Bay, related to ennvironmental factors. Int. Revue ges. Hydrobiol. 72(2): $121-146$

Kiørboe, T., Munk, P. (1986). Feeding and growth of larval herring, Clupea harengus, in relation to density of copepod nauplii. Environ. Biol. Fish. 17(2): 133-139

Kitchell, J. F., Stewart, D. J., Weineger, D. (1977). Applications of a bioenergetics model to yellow perch (Perca flavescens) and walleye (Stizostedion vitreum vitreum). J. Fish. Res. Bd Can. 34: 1922-1935

Kostrichkina, Y. E., Ojaveer, E. A. (1982). Long-term changes in zooplankton and growth rate of herring in the Gulf of Riga. J. Hydrobiol. 18: $37-43$

Kostrichkina, Y. E., Evtjukhova, B. K., Ojaveer, E. A., Belyashova, V. G. (1987). Some regularities of herring growth rate dynamics in the Gulf of Riga, 1960-1985. Comm. Meet. int. Coun. Explor. Sea C.M.-ICES 1987/J:11: 1-14

Lankov, A. (1986). The food of young Baltic herring Clupea harengus membras $\mathrm{L}$. in the Gulf of Finland. Comm. Meet. int. Coun. Explor. Sea C.M.-ICES 1988/J:4: 1-15

Lankov, A. (1988). On the role of the sprat (Sprattus sprattus balticus $\mathrm{Schn}$ ) in the ecosystem of the northern Baltic. Comm. Meet. int. Coun. Explor. Sea C.M.-ICES 1986/J:4: $1-15$

Laurence, G. C. (1976). Caloric content of some North Atlantic calanoid copepods. Fish. Bull. U.S. 78: 218-220

Laurence, G. C. (1990). Growth, survival, and recruitment in large marine ecosystems. In: Sherman, K., Alexander, L. M., Gold, B. D. (eds.) Large marine ecosystems: patterns, processes, and yields. American Association for the Advancement of Science, Washington, p. 132-150

Munk, P., Christensen, V., Paulsen, H. (1986). Studies of a larval herring patch in the Buchan area. II. Growth, mortality, and drift of larvae. Dana 6: 11-24

Øiestad, V., Moksness, E. (1981). Study of growth and survival of herring larvae (Clupea harengus L.) using plastic bag and concrete basin enclosures. Rapp. P.-v. Réun. Cons. int. Explor. Mer 178: 144-149

Ojaveer, E. (1981). Influence of temperature, salinity, and reproductive mixing of Baltic herring groups on its embryonal development. Rapp. P.-v. Réun. Cons. int. Explor. Mer 178: 409-415

Ojaveer, E. (1989). Population structure of pelagic fishes in the Baltic. Rapp. P.-v. Réun. Cons. int. Explor. Mer 190 $17-21$

Ojaveer, E., Lindroth, A., Bagge, O., Lehtonen, H., Toivonen, J. (1981). Fishes and fisheries. In: Voipio, A. (ed.) The Baltic Sea. Elsevier Scientific Publishing Co., Amsterdam, p. 275-349

Ostrowski, J., Mackiewicz, A. (1992). Feeding of herring and cod in the southern Baltic in 1991. Comm. Meet, int. Coun. Explor. Sea C.M.-ICES 1992/J:17: 1-15 
Oulasvirta, P. (1987). Spawning of autumn-spawning Baltic herring (Clupea harengus L.) in the Bothnian Sea. Finnish Fish. Res. 7: 31-37

Parmanne, R. (1992). Changes in the growth of herring in the northern Baltic Sea in 1970-1991. Comm. Meet. int. Coun. Explor. Sea C.M.-lCES 1992/J:42: 1-19

Parmanne, R., Kuittinen, E. (1991). Comparison of the fecundity of herring (Clupea harengus L.) in various areas of the northern Baltic Sea. Finn. Fish. Res. 12: 157-164

Parmanne, R., Sjöblom, V. (1981). Abundance, mortality and production of spring-spawning Baltic herring larvae in the seas around Finland in 1980. Comm. Meet. int. Coun. Explor. Sea C.M.-ICES 1981/J:23: 1-15

Parmanne, R., Sjoblom, V. (1982). Abundance, mortality and production of spring-spawning Baltic herring larvae in the seas around Finland in 1979. Finn. Fish. Res. 4: 20-26

Peltonen, H. (1990). Growth and mortality of Baltic herring (Clupea harengus L.) larvae in the Archipelago Sea estimated from length frequency data. Finn. Fish. Res. 11: $35-44$

Popiel, J. (1951). Feeding and food of the herring (Clupea harengus L.) in the Gulf of Gdansk and in the adjoining waters. Pr. morsk. Inst. ryb. Gdyni 6: 29-56 (in Polish with English summary)

Raid, T (1985). The reproduction areas and ecology of Baltic herring in the early stages of development found in the Soviet zone of the Gulf of Finland. Finn. Fish. Res. 6: $20-34$

Rajasilta, M. (1992). Relationship between food, fat, sexual maturation, and spawning time of Baltic herring (Clupea harengus membras) in the Archipelago Sea. Can. J. Fish. Aquat. Sci. 49(4): 644-654

Rajasilta, M., Kääriä, J., Eklund, J., Rantha-Aho, K. (1986). Reproduction of Baltic herring (Clupea harengus membras L.) in the sea areas of Turku, SW Finland. Ophelia, Suppl. 4: 339-343

Rice, J. A., Cochran, P. A. (1984). Independent evaluation of a bioenergetics model for largemouth bass. Ecology 65(3): $732-739$

Rudstam, L. G. (1988). Exploring the dynamics of herring consumption in the Baltic: applications of an energetic model of fish growth. Kieler Meeresforsch., Sonderh. 6: 312-322

Rudstam, L. G., Hansson, S., Johansson, S., Larsson, U. (1992) Dynamics of planktivory in a coastal area of the northern Baltic Sea. Mar. Ecol. Prog. Ser. 80: 159-173

Sparholt, H. (1990). A stochastic integrated VPA for herring in the Baltic Sea using acoustic estimates as auxiliary

This article was submitted to the editor information for estimating natural mortality. J. Cons. int. Explor. Mer 46: 325-332

Stardodub, M., Shvetsov, F., Hoziosky, S. (1992). The feeding of sprat in Eastern Baltic. Comm. Meet. int. Coun. Explor Sea C.M.-ICES 1992/J:26: 1-6

Thurow, F. (1980). The state of fish stocks in the Baltic. Ambio 9(3-4): 153-157

Thurow, F. (1984). Growth production of the Baltic fish community. Rapp. P.-v. Réun. Cons. int. Explor Mer 183. $170-179$

Urho, L. (1992). Morphological and ecological differences in the development of smelt and herring larvae in the northern Baltic Sea. Sarsia 77: 1-10

Urho, L., Hildén, M. (1990). Distribution patterns of Baltic herring larvae, Clupea harengus L., in the coastal waters off Helsinki. Finland. J. Plankton Res. 12: 41-54

Ustinova, L. (1990). Growth of the juvenile Baltic sprat Comm. Meet. int. Coun. Explor. Sea C.M.-ICES 1990/J:7

van Khanh, N., Drzycimski, I., Chojnacki, J. (1972). Feeding and food composition of sprat from Bornholm depth. Acta Ichthyol. Piscat. II(2): 55-66

von Bast, H.-D., von Oertzen, J.-A. (1976). Zusammenstellung von energieäquivalenten aquatischen Organismen unter besonderer Berücksichtigung der Ostsee. Wiss. Zeitschr Univ, Rostock, Mathemat.-Naturwiss. Reihe Heft 3 295-304

von Westerhagen, H., Rosenthal, H. (1979). Laboratory and in situ studies on larval development and swimming performance of Pacific herring Clupea harengus pallasi. Helgoländer wiss. Meeresunters. 32: 539-549

Wespestad, V. G., Moksness, E. (1989). Observations on growth and early survival during the early life history of Pacific herring Clupea pallasi from Bristol Bay, Alaska, in a marine mesocosms. Fish. Bull. U.S. 88: 191-200

Wiktor, K., Szaniawska, A. (1988). Energy content in relation to the population dynamics of Mysis mixta (Liljenborg) from the southern Baltic. Kieler Meeresforsch., Sonderh. 6: $384-356$

Zalachowski, W., Szypula, J., Krzykawski, S., Krzykawski, I. (1975). Feeding of some commercial fishes in the southern region of the Baltic Sea in 1971 and 1972. Polskie Arch. Hydrobiol. 22(3): 429-448

Zalachowski, W., Szypula, J., Krzykawski, S., Krzykawski, I. (1976). Composition and amount of food consumed by sprat, herring and cod in the Southern Baltic in the years 1971-1974. Comm. Meet. int. Coun. Explor. Sea C.M.ICES 1976/P:23: 1-13

Manuscript first received: December 2, 1992

Revised version accepted: March 29, 1993 